\title{
A Heavy Word: Discourses on Albanian Sworn Virgins
}

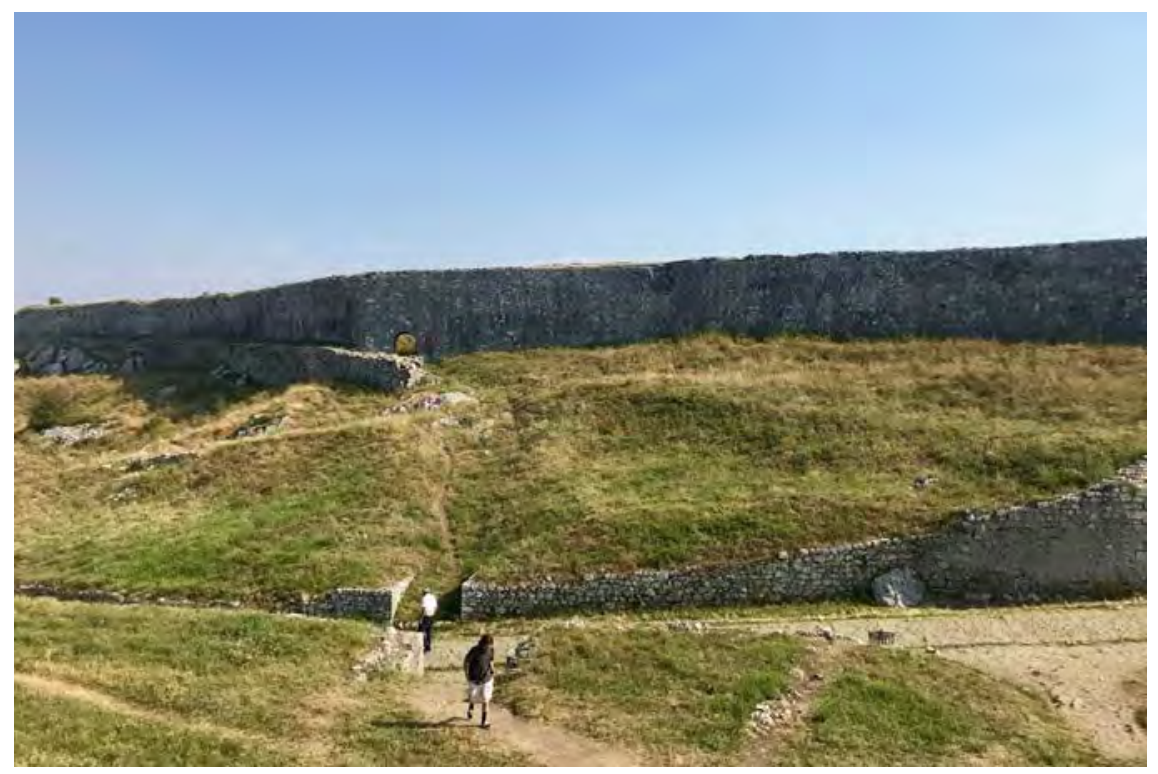

\section{Abstract}

This paper takes up the portrayal of burrnesha in media, where they are usually referred to as sworn virgins. Specifically, this paper utilizes news clips and informational videos accessible on YouTube in order to better understand the interplay of power dynamics between the West and Albania. The majority of these videos constitute a dominant discourse, aligned with most of the literature, that presents the custom of burrnesha as curious and anachronistic. This paper divides the pattern of Western engagement into four sub-themes: knowing, judging, finding, and dying. These themes are evident in the unequal power relations that allow the Western journalists to discover burrnesha, define them, and critique not only them, but Albanians and the Balkans more broadly. Indeed, the videos suggest that this practice is dying out on its own as the Balkans attempt to join modernity. The burrnesha themselves are un-

(C) Jeta (Jetim) Luboteni, photo and text, 2020

(C) Feminist Critique: East European Journal of Feminist and Queer Studies 2020, № 3, p. 65-89; http://feminist.krytyka.com (ISSN 2524-2733) 
derstood as forced into a male role that punishes the breaking of the oath of celibacy by death. However, the burrnesha, when interviewed, form a counter-narrative by complicating the rigid picture put forth in the literature and media. While they show nuance in their respective motivations, all show satisfaction with their lives. Finally, this paper reflects upon the interplay of the Western gaze, and the ways in which Albanian media interacts with its own people. I argue that most Albanian media distances itself from the burrnesha in order to make claims of being civilized vis-à-vis the straggling burrnesha who remain an anomaly to progress.

Keywords: Balkans, journalism, third gender, homonationalism.

he first time I heard about burrnesha is clearly imprinted in my memory. I was reading about Albanian culture on the internet when I came across an article that described this practice, among other things. This site described the "sworn virgin" as a woman who takes a vow of celibacy, after which society recognizes her/him as a male and affords her/him the role and rights of a man. According to this site, this custom was the only way out of an arranged marriage or a last resort for a family left with no male descendant, most often because of blood feuds. The negative framing of the practice did not dissuade me. On the contrary, it is difficult to put into words the surprise and joy I felt in finding out there was something in my culture that fit me perfectly. I had known for a long time that I wanted nothing to do with marriage, relationships or sex. I identified increasingly less with femininity, therefore, for me, it was not a question of whether I wanted to take part in the custom of burrnesha. Rather, it was something that was somehow always a part of me, but the name of which I found this day.

The irony of learning about a gender practice indigenous to my culture from a Western/English website was not lost on me. I was frustrated that I had gone for so many years in pain and confusion not knowing that burrneshas existed. Why had I not heard about the burrnesha from my family? ${ }^{1}$ Why did the Western sources know more about my culture and history than me? This paper explores several reasons for the disconnect between culture and memory. The aim of this paper is to situate the seeming re-awareness of the burrnesha within the context, described by Maria Lugones, of the replacement of pre-colonial genders with a Western capitalist-based gender binary (Lugones 2007). ${ }^{2}$ This paper focuses on the interplay of power dynamics be-

\footnotetext{
${ }^{1}$ I did hear the word used once, to connote a strong (married) heterosexual woman who 'gets things done.' It can be understood as a woman getting her value from being like a man, but it can also mean that the positive treatment of burrnesha exists in phrases that modern Albanians scarcely understand. This further reflects the "forgetting:" the notion of burrnesha exists, but the backwards actual practitioners have died. It is perhaps also a purposeful shifting of meaning towards straightness, to obscure what in Western gender norms is shameful.

${ }^{2}$ While it is a matter of debate if Albania and the Balkans experienced colonization, they clearly did not experience the level of destruction of indigenous "gender" that was imposed
} 
tween Western knowledge production of burrnesha and what can be understood as an Albanian media rediscovery of the custom. To better understand the modern iterations of the relationship between the Balkans and the West, this paper utilizes videos accessed on YouTube about burrnesha. ${ }^{3}$ These videos are particularly informative as they include foreign journalists visiting Albania as well as subsequent coverage by Albanian media. They illustrate the interplay of the Western gaze (in popular media and academia) and Albanians' understanding of themselves. What emerges from this analysis are much of the same hegemonic narratives I encountered when first learned about burrnesha, which present the practice as rigid and unfit for modernity.

I argue that the dominant Western narrative regarding burrnesha is problematic primarily because of the power difference between the Balkan subject and the Western observer. The latter has the authority to evaluate and define the former, because it has the backing of authoritative educational institutions and a history of power imbalance between it and the Balkans particularly in terms of politics and economics. The Western understanding of burrnesha presents them as victims of a backwards culture that forces women to choose between their femininity/sexuality and their rights. By contrast, I turn to the work of queer and decolonial theorists, such as Jasbir Puar, Maria Lugones, and Sara Ahmed to argue that burrnesha must be understood in more nuanced terms. I argue that we must listen to the burrnesha's own narratives of their lives and identities. Only when burrnesha speak for themselves does one hear the nuances to their stories, which run counter to the dominant discourse. For example, all burrnesha interviewed emphasize their happiness with their life, even while noting the difficulties they faced. They also show a variety of conditions and circumstances that led them to take on the role, ranging from simply not wanting to get married, to having to step up after a blood feud. Many cited masculine characteristics and some even describe having to convince their families to let them take this path. So, not only was taking on this role usually of their own free will, but it indicated their own internal identity. ${ }^{4}$ This is of great contrast to Western sources, which claim that this practice is wholly imposed and oppressive.

upon Native Americans or the Yoruba. However, it is clear that the imposition of western gender-regimes is an important part of the spreading of colonial hegemony, no matter if the region is directly or indirectly colonized. This is of course deeply tied in with race.

${ }^{3}$ One of the ways burrnesha are presented today in popular sources is on YouTube. Some of the videos first appeared on TV (particularly the case for Albanian clips) but others were made just for online video consumption. I used the search terms "burrnesha" and "sworn virgin" to locate videos on the subject. Overall, I review thirty-two YouTube videos. There were surely much more videos and documentaries about burrnesha, but if they were not uploaded on YouTube, I had no way of accessing them.

${ }^{4}$ It is possible that some may have retroactively created a narrative of male-ness. Yet, this is a human tendency more than anything, and to specifically target trans people to attempt to dissect their gender is problematic to say the least. 


\section{Knowing Burrnesha}

There is great power in knowing. Epistemic power on the part of the Western observer, combined with the history of power imbalance between the West and the Balkans, gives him/her authority when reporting on the Balkans. This is especially the case with the burrnesha, who have little power to set their own narratives. The European, usually Western, traveler and/or anthropologist has historically been the one that leverages their knowledge, often over the locals, and even over the burrnesha themselves. Part of the reason for this, is that no burrnesha are located in Western educational institutions and thus able to respond on a level playing field to the works written about them. ${ }^{5}$ This power imbalance is present in the videos reviewed, as well as both the anthropological sources, and the travelogues from the $19^{\text {th }}$ and $20^{\text {th }}$ centuries. ${ }^{6}$ It is striking to see that, though the media and time period is different, the general narratives have changed little from the nineteenth century.

Most popular reporting on burrnesha characterizes these subjects as mysterious, hard to find, products of the patriarchy, old, backwards, and dying out. By focusing on geography, particularly winding roads and mountains, and by occasionally using black and white, YouTube videos about burrnesha situate them physically and temporally distant from the present. The videos feed particularly on the curiosity created by anthropologists but also fiction writers, and the old travelogues to some extent. While there is some critique of the problematic representation of burrnesha, this does not negate the power of these images in shaping the popular imagination of the Balkan subject, and often even the Balkan self-concept. Indeed, this authority is not limited to Western media coverage, but also includes Albanian media. First, Albanian sources adopt the Western discourse on burrnesha. This places them in between the subjects and the authoritative observers: avoiding observation, and mimicking the hegemon, often in order to avoid implication in the custom. Second, to avoid association with this negatively framed custom, the Albanian sources distance themselves from it by further ceding authority to 'know' the practice to the Western observer. Albanians have their ways of understanding burrnesha, but those local ways of knowing are undermined by the Westerners who are assumed to hold superior knowledge.

\footnotetext{
${ }^{5}$ Burrnesha usually find themselves economically marginalized. This will be discussed in further detail further in this work.

${ }^{6}$ In particular, Antonia Young, but also Rene Gremaux, Whitaker, Edith Durham, and others. Durham's work, was not consulted closely as it is outside of the time frame of the focus of this piece, but the frequent citations of her by these and other authors (and media) warrant her mention. Based on those accounts, she possesses one of the most positive portrayals of the sworn virgins, yet still exercises authority over them. For example, the picture from her book is the image for the article on "sworn virgins" on Wikipedia. Yet, in the videos reviewed, Antonia Young has the greatest impact.
} 
One of the most influential anthropologists writing on sworn virgins, Antonia Young, is referenced in many of the videos, illustrating how her influence goes beyond just academia. Perhaps the most striking example of Young's impact not only on outsider perceptions of the burrnesha, but Albanians as well, is that of the Albanian news clip from 2013: "Virgjëreshat e betuara shqiptare" në fokusin e "Daily Mail" [Albanian sworn virgins in the focus of "Daily Mail"] (Ora News Lajme 2013). The title is the translation of 'sworn virgins' into Albanian, as opposed to the use of the native term (burrnesha), is cumbersome, yet telling. Accordingly, the reason the sworn virgins have become newsworthy is that 'our' tradition made it to the Western gaze. It is striking to see this Albanian video use clips of a famous video on sworn virgins by the National Geographic. This is because it would have been expected for the Albanians to know more about their own cultural custom, and therefore use their own footage and narrative. Below is an excerpt from the narrator of the video, which is particularly illustrative of the power that the anthropological approach holds over the self-image of Albanians:

Antonia Young antropolge dhe studijuse e ksaj praktike ne shqiperi, thot se femrat shqipetare ktheheshin ne burrnesha ne dy rraste: kur nje familje perbehej vetem nga gra edhe njera nga ato duhej te merrke per siper kte fat, ose ne rrastin kur prinderit vendoseshin per ta martuar vajzen dhe ato refuzonin. Burrrneshat apo Virgjireshat e betuara kurr nuk do te lajohen te te bejn serisht jeten e nje femre. Kjo do te ishe nje denim me vdekje per ta. Studjusja thot se kjo tradite e lasht para 200 vitesh ka lindur nga ligji tradicional verior, Kanuni i Lek Dukagjinit. Por si studijuse ajo thot se kjo praktik lejoj qe shum femra te shpetojn nga martesat e pa-deshiruara. Ajo thekson gjithashtu se kjo praktik jo vetem qe ju dha grave panvarsin port e te drejtat per te kryesuar nje familje. Interessant e thekson ajo qe shumica e burrneshave ndihen krenare per fatin e tyre (Ora News Lajme 2013, emphasis mine).

[Antonia Young - Anthropologist and researcher of this practice in Albania, says that Albanian women turned into burrnesha in two cases: when a family was comprised only of women and one of them needed to the take on this fate, or in the case of parents deciding to marry off the girl and she refused. burrneshas, or sworn virgins, will never be allowed to have the life of a woman again. This would be an act punishable by death. The researcher says that this ancient tradition was born two hundred years ago from the traditional law of the North, the Kanun of Lek Dukagjin. However, the researcher says that this practice allowed many women to be saved from undesired marriages. She emphasizes that this practice did not only give women independence, but also the rights to be the head of the household. It is interesting that she emphasizes that most of the burrneshas are proud of their lot in life.]

This video is particularly illustrative of the dominant discourse because of its emphasis on strict rules regulating the behavior of Albanian women. It attempts to clearly delineate the cases when a woman must give up her womanhood - for good. The death penalty for a burrnesha violating the oath of celibacy is constantly referenced in Western narratives on the practices, as 
it is here, and serves to present Albanians as uniquely violent and honor-obsessed. The video names the "Kanun of Lekë Dukagjin [Law of Lekë Dukagjin, a Medieval Albanian nobleman]" as the culprit for these conditions placed upon women, which as it mentions, is a body of traditional law with particular sway in Northern Albania. Though it is indeed highly patriarchal and somewhat influential across Albanian speaking areas, it is not the sole determiner or source of all Albanian behavior, just as any given holy text or constitution is not the sole determiner of the behavior of all the people in a particular religion or country. Over-emphasizing the sway of the Kanun on Albanians to this day locates them in the Middle Ages and presents them as pathologically patriarchal. Finally, this particular video does concede that burrnesha enjoy their lot in life, but it calls this "interesting," as if those assigned female at birth should be inherently miserable if they are not married with kids.

This video clip from Ora News is also noteworthy for its repeated deference to Antonia Young's authority on burrnesha (as emphasized). Sentence after sentence, the narrator repeats the word "studjusja [studier/researcher]," thereby letting Young speak for this indigenous practice. This repetition insinuates that Young is the true expert on this topic, and no Albanian can speak more authoritatively than her. The Albanian source might be expected to know more about burrnesha, owing to its proximity to the practice and geographically and culturally. Instead, the Albanian source alienates itself from this practice, thereby distancing itself from something it sees as backward. Another reason for the tone of deference in this except could be that the narration might have been translated directly from an English video that cites Young. It is not rare for Albanian media to translate news from English when it does not have to means to do original reporting. This would be understandable if the videos were on another country or topic, but it is quite astounding when done for an issue that Albanians would be expected to understand more intimately than foreign anthropologists. Furthermore, the excerpt above parrots the deeply entrenched narrative of strict rules and death for transgressing them, which is often sensationalized by the media. Burrnesha, and Albanian culture at large, are presented as backward, patriarchal, and violent. Therefore, it makes sense that the Albanian source surrenders authority to Young, in order to distance itself from burrnesha, by insinuating that they are remote, irrelevant, and only know-able by an anthropologist specifically looking for the odd and novel.

The dynamic of discovering Balkan oddities has historical roots. Ivan Jezernik, an author that writes about the travel narratives of the Balkans in general, and not the burrnesha specifically, provides pointed critiques on the ways in which Western travelers portrayed the Balkans. He states that, for the Westerner, there was "a strong sense of achievement if in the course of a tour he visited a spot 'where no European traveler had preceded him,' be it in the heart of Albania or ancient Macedonia" (Jezernik 2004, 30). This is painfully illustrated in the videos where journalists attempt to find burrnesha to interview. The emphasis on the mountains, in some cases referred to as 
the "accursed mountains"7 is meant to show how difficult it is to find the burrnesha. Journalists are considered deserving of applause for 'finding' these elusive burrnesha. One of the videos, published by Russia Today $[R T]^{8}$ in 2016, is particularly illustrative of the excesses of foreign journalists (Russia Today 2016). It renders the burrnesha as 'elusive' creatures antithetical to modernity, to be found and interrogated. This is not the first time Russia Today went to Albania to 'find' burrnesha. They also went there earlier, in 2009, where they interviewed Lali the first time (Russia Today 2009). Yet, in 2016, RT feigns surprise in encountering Lali, and says, "we were certain that burrnieshas $[\mathrm{sic}]^{9}$ only remained in the rural highlands, but suddenly we bumped into a sworn virgin in quite a large Albanian town" (Russia Today 2016). RT had already interviewed Lali seven years prior, in this 'town' (which is actually the port city of Durres, the second-largest city in Albania). The older clip does not go into the mountains like the 2016 report but does espouse its own set of problematic assumptions. Chief among them is the authority claimed by Albanian 'experts' interviewed, one of whom argued that these modern burrnesha are not observing the custom correctly and are instead 'pretenders.' They seemingly internalized an extreme anthropological definition of the custom, which holds that only an impossibly rigid Kanun definition is 'legitimate,' therefore it is impossible for this custom to exist anymore. However, I have not yet come across an academic source that argues with such force that burrnesha today are 'not really burrnesha.' Therefore, this seems to be another case of the internalized colonialism.

By and large, the methods with which the Western media come to know the burrnesha are highly problematic. For example, two of the most problematic videos depicted interviewers who simply showed up to the homes of burrnesha asking for an interview, as do many print journalists (SBS Australia 2010; Deutsche Welle 2013). Those interviewing seem to think that burrnesha owe them an explanation for their incongruity. ${ }^{10}$ Seeker Stories (2015) did use Diana in interviews, but at one point did not translate one of her key points: "As gje nuk kam te imponuar [Not one thing is being imposed on me]." The video instead created a narrative that argues that Diana's identity was unusual and oppressive.

Many of the videos are image-heavy, focusing on still images in a slide show, as if the burrnesha are some archaic specimen. The most overt example of this is a Belgian showcase of the pictures of the burrnesha in a gallery. This presentation completely silences burrnesha, and redefines them according to the Western gaze. This serves to subject the burrnesha - referred to as sworn

\footnotetext{
${ }^{7}$ Indeed, this is how they are often referred to in Albanian. But its use in videos serves to associate gender transgression with the Devil, curses, and evil.

${ }^{8}$ Russia Today is the state-owned media of Russia

${ }^{9}$ This RT documentary did not use the term Sworn virgins throughout. Its title screen was "THE VIRGINS," but it called them burrneisha (as opposed to burrnesha) throughout, perhaps because of a Russian pronunciation.

${ }_{10}$ This is not unlike trans people in general, who are often faced with invasive questions which they are expected to answer at any given time.
} 
virgins and men-women - to the way the West sees them, rather than letting them speak for themselves in any way. They are displayed like relics at the worlds' fair. The video, however, has a voice, and its opening slide puts into words what it and many videos claim or hint:

\title{
SWORN VIRGINS BY PEPA HRISTOVA
}

\author{
In northern Albania, in the Cursed Mountains, said to have been created \\ by the Devil himself, the tradition of the "sworn virgins", \\ Europe's last men-women, lives on. \\ The Kannun, a collection of laws from the Middle Ages, \\ passed on for generations by word-of-mouth, permits \\ families to replace the male head of the household \\ with a woman in the case of the patriarch's death. \\ These "oath-virgins" or Burrnesha not only receive \\ the status but also the rights of men and are highly respected \\ in the family. They adapt to their roles so perfectly that, \\ over time, they are no longer recognised as women \\ outside of their families. Over the years, \\ the woman in them is lost.
}

This excerpt has no qualms about ascribing devilishness to the burrnesha, as if their gender deviance, and remoteness makes them 'fallen from grace' as the devil. This type of narrative is not unique to Albania or the Balkans, in fact, Lugones (2007) shows similar attitudes toward indigenous people in general, and their gender practices in particular by the colonizers. However, it does not suffice for the burrnesha to be living as cursed mountain-devils, they must also disappear. On the contrary, the phrasing "Europe's last men-women," connotes that they are the worst of Europe, the most backward, and thus destined to die out soon. Referring to the Kanun as transmitted by 'word-of-mouth' suggests that Albanians are illiterate and backward. The rest of the excerpt mourns the 'loss' of the femininity to the pathologically patriarchal Albanian culture. Indeed, the whole aura of the video is sad and dark. However, the video does not mourn the burrnesha themselves, but they mourn the female, as if to argue that they need to save Albania from its own backwardness that allows this tradition to continue to live, albeit with its date of death fast-approaching. Even more so, far from being truly liberatory, this narrative is transphobic and gender-essentialist. It, like colonialism, is hidden behind a concern for the women, to save them from their men and culture, and to place them all under a benevolent new regime. ${ }^{11}$

\footnotetext{
${ }^{11}$ Of course, the colonization of Albania is not the same as that of Afghanistan, for example. And there is significant debate on whether Albania can be considered colonized. But I argue that the post-communist and post-war relations between Albania, Kosovo, and the West, can be considered a kind of colonization even if 'just' culturally and economically.
} 
Just because the burrnesha are celibate, does not mean they cannot love or have meaningful platonic relationships. Nor does it mean they are miserable, contrary to what many of the journalists seem to suggest. On the contrary, all of the burrnesha interviewed were quite happy, some more than others. One example of this was when they were pressing Lali about not missing out on love, to which he replied: "Ku ka dashuri te sinqert sot, pppfff [Where is there sincere love nowadays, come on]." He countered: "Jam I dashuruar: me natyr, boj foto ... [I am indeed in love - with nature, I take pictures...]" (Ora News 2018). This illustrates Lali's happiness with his life, despite the fact that it might not seem as such to others. Furthermore, he turns the discourse of love on its head: he shows the limitations of confining love to a heteroromantic sphere and makes a criticism of the often-shallow ways many people express love.

\section{Judging Burrnesha}

This paper reviews videos on burrnesha, accessible on YouTube, from media mostly located in Western Europe or Albania. Some of these videos contain interviews with the burrnesha. Videos where the burrnesha are not given room to speak and instead are subject to Western depictions almost exclusively fall into a hegemonic dominant discourse that is over-simplified, negative and problematic. But, when burrnesha are given a chance to speak, they constitute an alternative discourse that asserts their agency and satisfaction in their own lives. This is despite tolerating prying and offensive journalist questions and stereotypical video and photo positioning. Yet, overall, in the videos it is clear that the outside observer has the power to define and judge burrnesha, and this is evident across much of the videos.

Both the videos and literature reviewed favor the term 'sworn virgin' to refer to burrnesha. While this is indeed the term used in English, it leaves one to wonder about the origin of this phrase, particularly because of its connotations. First, it emphasizes the binding nature of the oath as well as the virginity centering male control. This casts burrnesha as victims of their culture, and presents the Balkans as the [last] bastion of patriarchy in Europe. Furthermore, it places the focus on sexuality as opposed to gender. This occurs alongside the sources' insistence in gendering burrnesha as female, even while simultaneously noting their role as men and usual use of male pronouns. ${ }^{12}$ As Aleksandra Horvath critiques, "S/he is seldom, if ever, perceived or referred to as male, except in those cases when a traveler is deceived by his/her male looks and manners" (Horvath 2009, 3). This further essentializes gender: the authors describe burrnesha's masculinity/male gender, while persisting to

\footnotetext{
${ }^{12}$ While Dickemann, like Young, chooses as an anthropologist to state that the "sworn virgins" are male and use male pronouns, she, nonetheless, continues to refer to them as female (Dickemann 1997, 201).
} 
refer to them as female. ${ }^{13}$ For example, Young states "there are many different terms used to refer to these women who fill the place for which there is no man, although none of the (approximately fifteen), I have met, seemed aware of any special term, preferring to think of themselves simply as men" (Young 2009, 63, emphasis mine). Again, Young here invalidates their preferences immediately after presenting them. Even more so, she holds herself in a higher position of knowledge than the subjects by saying none were 'aware' of a term to refer to themselves, other than "men." Yet, compared to the offensive over-generalization many $19^{\text {th }}$ and $20^{\text {th }}$ century travelers to the Balkans made, Young and most modern anthropologists are much more respectful to those they study, even when imposing (even unintentionally) gender essentialism. Overall, the anthropologists/Balkan travelers are therefore straightening and invalidating the preferences of the burrnesha. This is also a central tendency of the YouTube videos, because they follow in the footsteps of anthropologists - without the intellectual backing but still making authoritative and influential claims.

Aleksandra Horvath, the author of a pointed critical article on burrnesha, makes successful use of the Montenegrin term "tobelija," which gives autonomy to the people to name themselves. In only six pages, Horvath provides a much better picture not only of burrnesha, but also of the power dynamics involved in the western gaze towards the Balkans. The Western travelers seek to discipline the tobelija as they would flora or fauna, and they exercise power over them by placing them into "a strict dimorphic gender system, the same one that reinforced normative heterosexuality and bourgeois marriage values in Western Europe at the time" (Horvath 2009, 5). This is of course painfully evident in the videos, as many of the interviewers repeatedly pester burrnesha as to why they would renounce sexuality, whether they have been in love, or whether they would wear a dress. Overall, there is no respect for other ways of living: the only acceptable way is a heterosexual life, and burrnesha's refusal of that warrants interrogation and disapproval.

Likewise, in her chapter on "Balkans sworn virgins," Mildred Dickemann questions the controlling narrative on burrnesha (Dickemann 1997). ${ }^{14}$ While her work includes the observations of anthropologists such as Durham, Rene Gremaux, and Ivan Whitaker, she applies a critical lens to them. She counters their overarching claims by stating, "I believe these canonical rationales gloss over the complexity of the motivations and the agency of several ac-

\footnotetext{
${ }^{13}$ This refusal to see the burrnesha as male is akin to the narrative of Trans Exclusionary Radical Feminists in the United States, which refuse to accept trans people, in particular trans women, as valid.

${ }^{14}$ Though this paper does not take up the issue of religion and burrnesha in detail, it is important to note that the book in which Dickemann's work is included is titled Islamic Homosexualities. Almost no other source discusses Islam, but they do occasionally reference Christianity. This is indeed an area in need of much more discussion, particularly in connection to race and racialization of religion.
} 
tors, including the individual concerned" (Dickemann 1997, 198). She adds, "Even more significantly, few accounts reveal the motivation of the individual herself in becoming a surrogate son" (Dickemann 1997, 199). Dickemann's points are supported by some of the videos: when burrnesha speak in Albanian, they talk about nuanced and varied motivations for making the choice that they did. However, much of this is lost in the translation. This is even more so the case when they are simply photographed and not given an opportunity to speak. Burrnesha show a strong personal identification and satisfaction with their role that is lost on the narrative that centers on rules and blood-feuds. ${ }^{15}$ Dickemann even shows a bit more nuance in the rule of celibacy, whereas all nuance is lost in the videos. She says that "sources overall suggest to me and Gremaux that heterosexual sex was extremely uncommon" (Dickemann 1997, 201). This is distinct from the videos, which presumably seek to show Albanians as uniquely backward and violent - that they will unequivocally kill a "woman" for having sex. Dickemann instead does not make an absolute statement of celibacy, but fairly presents it as the (respected) centerpiece of the role.

One video that is a lampooning of the celibacy of the burrnesha is a particularly offensive Albanian comedy clip simply titled "Burrnesha." With Albanian traditional music playing in the background, the video shows a reporter walking into the mountains. If this sounds familiar, it is because it is a caricature of the usual videos on sworn virgins. It shows a burrnesha with makeup, a skirt, fancy heels, but also a gun. Her outfit is mismatched. Her gender performance is there for comedic relief. A man who is apparently, her husband says: "kush o moj burrnesh [who is it, o burrnesh]." She says "pun gazetaresh doken ... ndoshta dojn naj intervist per njerzit e ngujume [looks like journalists, perhaps looking for an interview of isolated people]" (TV 2000 2018). The journalist arrives and says "miredita zoj [good day ma'am]," and she gives him a hard handshake, which ushers in a laugh track (TV 2000 2018). The journalist goes inside the meager home to interview the disheveled, longhaired man, who does not leave the house for fear of being killed for blood. This simultaneously casts the men as hyper-masculine (insatiable for blood) and effeminate (so scared to leave house that the woman has to carry a gun and stand guard).

When the journalist comes back outside, he inquiries about the woman's undergarments set out to dry. The woman describes that each of her clients prefer a different pair, insinuating that she is engaged in some type of sex work in the village. Clients include politicians, village elders, and shopkeepers. The journalist says: "paske shume pune [you seem to be very busy/have a lot of [sex] work]," to which she replies: "po ne per nje nderr rrojm morr

\footnotetext{
${ }^{15}$ Of course, one can claim that people make up cross-gender narrative in hindsight, but this is an accusation usually levied at trans people to delegitimize their identities, and naturalize firm gender essentialism (Dickemann 1997, 199).
} 
burr [But we live for honor good sir]," which is the punch line of the clip, and the end of it (TV 2000 2018). This insinuates that the villagers are pathological hypocrites, whose word means nothing and who have no honor. The video seems to suggest that their gender transgression and isolation makes them particularly sexually licentious, and that those that claim celibacy are the most perverse.

This comedy clip is in many ways unsurprising, as Western travelers have made similar claims. Leo Brenner-Gopcevic's insinuation that the sworn virgins are in fact not virgins and break their oaths, mirrors the "punch line" in the comedy (Horvath 2009, 4). Brenner taunts them to be careful not to get pregnant because their barbaric culture will have them killed. Likewise, "Steinmetz describes the morality of the local population as being lax, and provides the additional detail that the particular tobelija he met was ugly, which is the reason he gives for why she opted to become a sworn-virgincross-dresser" (Horvath 2009, 4). This mirrors the gaudy depiction of the burrnesha in the comedy, as well as run-of-the-mill transphobia.

At first glance, it is odd that such a negative portrayal would come from Albanians themselves. However, as with most of the other videos, the Albanian treatment often outdoes the Western one in contempt for the tradition and mountainside. One explanation for this can be that it is an attempt by the city-folk to ridicule the rural people for the sake of recovering dignity in the face of Western domination. Many Albanians, especially the city dwellers, see burrnesha, and villagers in general, in a negative light: as if they are remnants of the past, which need to be civilized. Urban, nationalist Albanians (who in my experience also identified with the Communist regime and who seek heterosexual prestige) wholeheartedly accept this kind of discourse.

To be sure, other videos have their share of rude depictions, more than can even be summarized. Most videos take serious issue with the requirement of celibacy. No matter the language, they frame it in terms of sacrifice. For example, in describing Lali, Ora News states that "Vendim e ka par per ti shpetuar dominimit te meshkujve ne nje shoqeri patriarkale si kjo e jona, qmimi per ta paguar eshte virgjiria [He saw this decision to escape the domination of men in a society as patriarchal as ours is, and the price to be paid is virginity]" (Ora News 2018). This is milder than other videos, but still frames virginity as a price paid for freedom. One video in particular, pushes this narrative to its ethnocentric extreme: "Women Forced to Live as Men" (SBS Australia 2010). If the title is not offensive and inaccurate enough, it proceeds to argue that because Albanian men cannot stop killing each other, some women need to become men. Such an assertion is rife with ethnic connotations about the backwardness of Albanians, and, as in the comedy clip, emasculates them (Yuval-Davis 2003, 27). This video, like many others, takes place in the mountains and begins with Albanian traditional music so as to set the stage, culturally speaking. They describe burrnesha according to the mainstream narrative, situating them as a product of patriarchal law, and introducing the 
burrnesha as "a woman who is forced by tradition into a startling transgender transformation, required to act and live as a man" (SBS Australia 2010). The terms "forced," and "required," as well as the phrase "startling transgender transformation" not only emphasize the oppressiveness of the practice, but also appeal to transphobia by associating gender transgression with backwardness. Such a description completely converts the practice into the discourse of colonial gender, doing great violence in the process.

Another example of distasteful treatment of burrnesha by Albanian media is asking if they have ever tried on a dress or if they were ever in love (Tujani 2016; Vizion Plus 2014). One journalist even had the audacity to bring in a 'gift' for one burrnesh, Justina (RTV Klan 2015). The gift was a dress, which the journalist asked Justina to put on, and of course, Justina refused. This is clearly quite disrespectful to Justina's autonomy as a person. Justina's orientation and life trajectory are troubling to the journalist, who would like to see Justina in a dress instead. Time and again, the Albanian media outdo their Western counterparts in disrespectful engagement with the burrnesha, as no Western media has had the gall to suggest such a thing.

\section{Finding Burrnesha}

For the Western traveler, the sworn virgins are seen as "the remnant of something primeval, the embodiment of a stage of cultural development that civilized societies have already passed through, part of civilization's early childhood" (Horvath 2009, 4). Therefore, they are seen as a past European state: as if Europe could learn about itself by looking back in time at its backward internal Other. Dickemann shows that this argument has been made explicit at least once:

Are the only known institutionalized female to male role and identity transformations in modern Europe, paralleling those known from native North America (Blackwood 1984; Lang 1990). Indeed, Scandinavianist Carol Clover (1986) has proposed that they represent a surviving example of cross-gendered female roles widespread in pre-Christian Europe, as evidenced by sagas, folklore, and early, Christian accounts. In fact, their former presence in now urbanized Dalmatia and Bosnia is attested by epic folksongs (Dickemann 1997, 197).

This serves to categorize burrnesha with other 'third gender' practices, but also as the 'last frontier' of civilization in Europe. Note the use of the term "survive:" somehow, Albania has sheltered what could not live in Christian Europe. With the passage of time, perhaps Albania too would learn to be properly European, and the dying out of the burrnesha might be a testament to this. But the burrnesha are a testament to the ability of the Balkans itself to harbor backwardness, as Horvath states: "epitomis[e] all that is exotic, strange, and 
primeval about the remote and mountainous regions of the Western Balkans during this period" (Horvath 2009, 1). Therefore, in focusing on them, Westerners can make claims about the Balkans in general, as well as their superior position to them. ${ }^{16}$

In many ways, the Western gaze is reflective. Horvath explains that "as Comaroff and Comaroff remark, colonialism, either narrative or political and economic, was not only about forming the periphery but also about forming the centre" (Horvath 2009, 5). Therefore, Europe learned/learns about itself by juxtaposing its achievements with the Balkans. What these achievements were varied over time. At the time of these travel narratives, Europe was trying to control and discipline bodies as part of industrialization and colonization, especially with theories of Darwinism (Horvath 2009, 2). This would help justify Western superiority while subjecting the populations to total intellectual subjugation, concurrently in many cases with physical subjugation. Nowadays, this is still the case to an extent, but with the 'achievements' of gender liberation and LGBT rights, perhaps the West would like to look at its past self (the Balkans) and feel proud about what it allegedly overcame. It is also possible that the emphasis on third-genders (not just in Albania) is part of a search to legitimize sexual and gender minorities as a thing that has always been a part of humanity.

One of the major themes in the video is that of distance: both physical, and temporal. Jezernik argues that though "there has never been much disagreement about [the] non-European character [of the Balkans] or its intention to Europeanize itself [...] After the age of Enlightenment, the Balkans was perceived at once near (geographically) and far (culturally)" (Jezernik 2004, 25; see also Rexhepi 2016). It is almost as if he is watching these videos himself. Combined with Ahmed's claim that "bodies as well as objects take shape through being orientated toward each other," Jezerniks argument helps to unpack the dynamics of the journalists' search for the burrnesha (Ahmed 2006, 54). Her points about the Orient and distance are also very relevant, as well as ideas of farness and reachability (Ahmed 2006, 114, 117). Western Europe is in a way going back in time via distance and remoteness and finding their ancient cousins who have not yet evolved to whom they can compare themselves. Burrnesha's orientation is perhaps especially troubling for Western gender regimes, because they are not oriented to anyone. As Prend says in the end of his interview:

Kanuni thonke burrneshat si rrine. Ajo duhet me shkue drejt Zotit mendes tende te fort edhe me hec me burra. Un jom ka rri me ty sonte se se kem kurxho shoqen kur njoni, jem ka rrin bashk dy sonte, jena vlla e moter mos dajt Zoti. A je ka kuptu? At her une kom shku drejt githmond me mendje te Zotit ne qjiell edhe ton dynjaja mu ka duk vlla (Russia Today 2016).

${ }^{16}$ Furthermore, Horvath's work makes clear the need to further investigate the mechanisms of racialization of the Balkans, especially regarding race and religion. 
[The Kanun says burrnesha stay as they are. She needs to go towards God with a strong mind and to walk among men. I am sitting with you tonight and we are not related nor friends, but tonight we are sitting together, we are brother and sister, ${ }^{17}$ may God never separate us. Do you understand? So, therefore, I went forward always with my mind towards God in Heaven and all of humanity was my brother.]

Prend shows his understanding of all of humanity as his brothers and sisters, which connects him to them in a familial way, thereby wholly ruling out sexuality. He also says that burrnesha are to be oriented toward God, and walk among men. Therefore, Prend is oriented not toward another person romantically nor sexually, but still possesses a fulfilling path in life. Other burrnesha have talked about how they are focused on music, the mountains, art, etc., rather than being oriented to anyone sexually. This does not fit well into Western cosmology, particularly in the context of a neoliberal/colonial gender regime. Nevertheless, burrnesha report satisfaction with it.

Ahmed's contributions are great when applied to the 2016 Russia Today report, which interviews four "burrniesha [sic]" (Bedri, Lali, Nadir and Prend), and is rebuffed by at least one (Haki). The video is structured a "wild goose chase," with a handful of dramatic flashbacks throughout of Bedri talking about his life (Russia Today 2016). The video is reminiscent of Animal Planet, as if the journalists were looking for a rare but dangerous animal. In the introduction to the video, the Australian narrator says they are "looking for sworn virgins who uphold a mediaeval highland tradition. Several times we thought we'd manage to pick up their trail but somehow they always managed to slip away," leaving the viewer with the impression that they were trying to catch a wombat or Tasmanian devil (Russia Today 2016). They had an Albanian journalist, who, as can be expected by now, attempted to outdo the Russians in disrespect for the burrnesha, to civilize himself by comparison. They stop to ask for directions through the villages and winding roads. The people giving directions are usually Albanian men, who are all shown pointing in the direction of the burrnesha: orienting the journalist toward the oddity/undesirable. Ahmed's theory of orientation here is invaluable to critique this (Ahmed 2006). The foreign journalists can only find the 'unreachable' burrneshas through locals (racialized/backwards) pointing and orienting the Western journalists to the dying deviants. It is as if they are pointing back in time. As is the case when traveling at the speed of light: the farther the journalists drive, the farther back in time they go. Finally, the pointing is terminal and therefore necropolitical: the journalists can proceed to pester the undead burrnesha and leave the other Albanians alone, as they are comparatively more modern and acceptable - for now.

When the journalists finally reached Haki, they sent their Albanian journalist to speak to him first. Note that he called Haki "Hakije" and referred

\footnotetext{
${ }^{17} \mathrm{He}$ is being interviewed by a young woman.
} 
to him as female, even though Haki has made clear in other interviews that he used male pronouns. Haki wanted nothing to do with this interview, even "mdhafsh florije [if you give me gold]" (Russia Today 2016). After this failure, the Albanian journalist runs back to the car, and recounts how he felt threatened after Haki told him to get lost, because he realized Haki had a gun and could have trapped him with his cows (Russia Today 2016). This scene is uncannily similar to a passage cited by Horvath of a traveler named Schultz who described burrnesha. He:

portrays the inhabitants of the Balkans as completely uncivilized, adding a romantic flavour to his account by describing how it was only on his third attempt, on horseback and without the Sultan's permission, that he managed to penetrate into the inhospitable region of northern Albania ... His transvestites are said to "shoot like mad", and are described by him as having renounced "the greatest happiness" i.e. marriage (Horvath 2009, 4).

It is as if his work is a transcription of the video itself, as it describes all the themes: that the burrnesha are troubling the reporters, that they are remote, violent, and stupid. It begs the question of if Russia Today and other productions are knowingly referencing this discourse, or if they are oblivious and full of their own stereotypes that they, like Schultz, present such terrible descriptions.

Amazingly, after interviewing Lali and Bedri (whom they also treat disrespectfully), the journalists head back to try with Haki again! But this time, they send a reluctant Lali to talk to him. Haki is of course not convinced, and is secretly recorded telling how he was mistreated by other journalists promising him they would help him get retirement benefits, who wasted his time, who made fun of him and his family, and disappeared. ${ }^{18}$ The narrator says: "the further and higher we went into the mountains, the more desperate we became. Without realizing it we had become embroiled in the complicated dynamics between the last remaining upholders of a medieval tradition and journalists" (Russia Today 2016). First, of course the "dynamics" between exploitative foreign journalists and burrnesha would be complicated, yet this narrative blames burrnesha for it. Overall, they felt the need to show the trouble burrnesha caused them, but not the trouble they caused the burrnesha. Second, describing the burrnesha as "last upholders of a medieval tradition" sanctions the burrnesha for death.

It is interesting that a Russian media agency is engaged in such negative treatment of burrnesha. To be sure, they are far from the only ones, but they are one of the worst offenders reviewed here. Their geopolitical motivations in the Balkans and in general help provide a glimpse as to their motivations

\footnotetext{
18 "I kan thon [vllaut] jon kau lidhin pension tonave e jon ardh e ka rra e kom hup dy ore qaty me ta e masi mandej jon tall me neve e jon shku ne pune te vet." Translation: They [journalists] told him [Haki's brother] that they would get us retirement benefits and they came and I wasted two hours with them and then they made fun of us and went on their way.
} 
for such a report. As Horvath states: "The exoticizing of the peripheral, present in almost all early accounts of tobelijas and embodied in patronizing, sardonic, and infantilizing narrative strategies, could be viewed as a kind of exclusion, taking place simultaneously with processes of normalization back at the centre" (Horvath 2009, 5). In this way, perhaps Russia is attempting to normalize itself vis a vis the homophobic laws enacted of late, at the expense of the Albanians. Furthermore, their support for Serbia would render them interested in anything that would make Albania look bad.

The Albanian sources also create geographical distance from burrnesha despite inhabiting the same country. One of the only videos from Kosova visits Mire Lajqi in Rugova, and is also the only video in which they ${ }^{19}$ appear (Klan Kosova 2017). The video is in black and white and begins with a pan of the mountains and old man playing traditional music, which, much like the foreign videos, situates the burrnesha in the time before modernity. Before the interview, the reporter introduces the practice very much according to the dominant discourse. She calls the rules that brought it "te egera [wild]" (Klan Kosova 2017). The screen then shifts back into color and strongly reinforces the reporter in saying "Kjo jete primitive ne nje shoqeri patriarkale te asaj kohe po vazhdon edhe sot [This primitive live in a patriarchal society of the past continues even today]" - thereby positioning Mire as a living remnant from the distant past (Klan Kosova 2017). The video does concede and describe Mire as taking the role "me vetdeshire [Of their own wishes]," but also says that they are "E fundit ne anen e rrugoves [The last in the Rugova valley]," asserting that Mire's wishes are anachronistic (Klan Kosova 2017). While emphasizing that Mire is the last in burrnesh in Rugova, the camera focuses on their wrinkled mouth and eyes, to further emphasize that 'the days of this tradition are numbered.' The interview portion of the video is much less alienating, but the introduction and cinematography is so Othering that it outdoes many of the Western productions on which it is clearly based. It begs the question as to why KLAN Kosova wanted to make this report in the first place. They seem to have forgotten their tradition and only re-discovered it after the West pointed, or oriented, them toward its oddity and newsworthiness (Ahmed 2006).

\section{Dying Burrnesha}

The final major theme found across the sources is the discourse of dying. The videos seem to suggest that certain orientations and positions are unlivable as Albania increasingly opens to the global economy and its corresponding gender regimes (Ahmed 2006, 99). Following Jasbir Puar, it is clear that burrnesha are anything but "properly queer subjects," primarily because they are

\footnotetext{
${ }^{19}$ I use "they" as Mire's pronoun because in the video Mire shifts back and forth from the masculine to the feminine in this clip, as do many of the other burrnesha.
} 
submitting to a patriarchal culture (Puar 2008, xiii). Instead, they should be submitting to Western capitalism in order to truly be free (i.e. homonationalism). Therefore, they have been "targeted ... for death," not by bombing, but by a slow dying-out (Puar 2008, xii). The images of wrinkled, ill, old 'women who became men' in popular media confirm this, and make death seem inevitable.

A piece by ITV News that seems to be a part of a larger documentary heavily relies upon this narrative. It is titled "The 'sworn virgins' of Albania: Women who have lived their whole lives as men" (as usual, calling them women). This production interviewed a few burrnesha, but the clip does not show any interviews besides that of Bedri. The clip focused on the story of Shkurtan, who is now very old and confined to his bed, and yet ITV news had no qualms about interviewing him in that state. In fact, it helps their argument by showing that the burrnesha are literally dying off. It says that he "was forced to live as a man ... Now close to ninety, he says it was an honor" (ITV 2018). This in a way does honor their lives, yet the use of the term 'forced' is again meant to justify the dying-out of the practice. It continues on this trajectory: "there are only around twenty sworn virgins left, and as cultural change comes to Albania, they may become a thing of the past" (ITV 2018).

Not all of the sources agree on the prognosis of the burrnesha. One point of distinction is made clear in noting the association between Dickemann's critical approach and her conclusion that "it is too early to conclude that the institutionalized cross-gender role is a thing of the past" (Dickemann 1997, 202), as well as Young's anthropological approach and her claim that the practice is dying. Young states that she has "not yet met any child who is being brought up to be the next generation's sworn virgin (Young 2010,67). She predicts, however, "due to rapid social changes, this traditional gender role change will probably die out within a generation or two" (Young 2019, 68). It is an almost fatalistic prognosis: that the burrnesha are destined to disappear, and be replaced by a more enlightened Western gender regime.

Maria Lugones is essential for understanding the colonial use of gender, and the distinctions between the regimes it imposed in Africa and the Americas, to the gender system it imposed in the core (Lugones 2007, 186). These systems destroyed traditional ways of knowing and living, and made colonial subjugation possible. Furthermore, she argues that patriarchy is not the inherent historical state of all humans. The narrative of "this mythical starting point," where "other human inhabitants of the planet came to be mythically conceived [...] as an anterior stage in the history of the species, in this unidirectional path" is particularly relevant to the Western conception of the Balkans (Lugones 2007, 192). Again, though Albania was not militarily colonized as was the case in modern day Nigeria or Mexico, it is subjected to these narratives of primitivism, patriarchy, and progress. However, in the case of the Balkans, it seems Europe sees more of itself than in it has in its African, Asian, and American colonies. This is, of course, a product of racist thinking. Triumphant Europe looks back at its fallen cousins, in this case the Albanians, 
from a point of the most 'advanced' gender regimes - where it has overcome patriarchy and homophobia, and now can lament the rest of the world for remaining back in time (Lugones 2007, 192, 196-197). It need not remember how it treated, and still treats, Western women.

Saffo Papantonopoulou brilliantly develops the concept of "economies of gratitude" which is "an attempt to hail the transgender subject into a debt of gratitude toward neoliberalism" (Papantonopoulou 2014, 281, 290). In this context, Albanians would have to be forever grateful to the West for ridding them of their backward customs and for bringing them into capitalism. They would then have to respond with Islamophobia and racism to whichever Other fits the bill. She shows that in the film Dangerous Living: Coming Out in the Developing World, showing that "queerness/gayness and sometimes transness (when it is acknowledged) were invented in the West" (Papantonopoulou $2014,288)$. This narrative is often taken up by decolonial struggles, but in the opposite direction: that the West invented queerness, and thus all queer members of society are either traitors or must be eliminated. In this vein, it is unclear if the burrnesha are being increasingly conceived of as LGBTQI+ and thus a Western colonial invention, which is ironic, not to mention violent. But it is to be expected, as racialized queer subjects always suffer the most in the tugand-pull between colonization, pinkwashing, neoliberalism and nationalism.

These videos show but do not adequately discuss the difficult economic state of these burrnesha. It is interesting that many of the videos show how important the burrnesha were to the economic survival of their families, either when they needed an extra hand or when they had no male heir. They usually passed the family fortune on to their nephews. Today, however, many burrnesha live alone and in poverty. Prend talks about how poverty made him small, so even smaller than all the men when he would go to male-only gatherings ${ }^{20}$ (Russia Today 2016). ${ }^{21}$ In the 2016 RT video, Bedri cuts off the interview after being told by a friend that interviewees should be paid more. It seems $R T$ was only going to offer him about 50 euros for all of his time and emotional labor. He mentions that the villagers will consider him a sellout if he gives interviews. Yet he put his whole reputation on the line to give $R T$ an interview as he is doing his friend Lali a favor and is in a difficult situation as a taxi driver in a village trying to raise his brother's kids.

20 "Githmond un per veten time kur kom shku ne mledhje, o kom shku ne pamje, o kom shku qeshtu, une kom nxon vend ma pak se I tjetri. Se boll e vogel jom po edhe ma fort jom zvogglue. De me thon ma e varfer. Sa I varfer njeri kur ska [?] me I para." Translation: "I always went on my own to village meetings, or to express my condolences [to families of the deceased], or I went to such events, I took up less space than anyone else. I am small enough but I have shrunk even more. Meaning, I am poor [not well fed]. How poor a person is when they don't have [?] more money."

${ }^{21} R T$ treated Prend much better than the other burrnesha, probably because the Albanians with them on that journey were not journalists, but blood feud reconcilers who have had significant experience in the mountains. They set a much more respectful tone towards the burrnesha. 
Many of the Burrnesha reveal in their interviews the great help that they were to their families. Mire explains how they: "Kom naj, kom naj me burra, skom naj une me fmi ... pleqnor, te zot, qe kan dit me fol, qe kan dit me te eduku ... [dhe kom rrujt dele] deri ne 400 copa [I stayed with men, I did not stay with kids ... wise old men, that knew how to talk, that knew how to educate ... [and I managed sheep] up to 400 of them]" (KLAN Kosova 2017). Nadir, Bedri, and Prend likewise made great contributions to their extended families: by taking care of children and property (Russia Today 2016). Few reporters truly appreciate this. For example, regarding Mire Lajqi, the reporter says "me krenarije jetoje jeten e nje burri, ku edhe sot me shume xhelozi vazhdon ta mbaj ket perbetim [They lived their lives with pride, who to this day with much jealousy continues to keep this conviction/oath]" (KLAN Kosova 2017). Of course, Mire would be proud of what they did for their family and would not want to change at the very end of their life. Yet, the reporters seem to consider this conviction a jealous one, which, especially when considering Mire's contributions, is particularly ironic. However, in the context of the nuclear (and neoliberal) family, the sacrifice of Mire and other burrnesha becomes invisible and unnecessary. There is little value and place for a contribution like Mire's, helping with subsistence farming, in neoliberal economies. In fact, Mire says: "qajo si pom sheh jom kon tona her edhe jom, dej te des. Kur te des tem gjujn dikund most e kan dert per mu hiq, ma kan pa hajrin sa ma kan pa, tash sma sheh kerkush [As you see me, I have always been, and will be until I die. When I die, they can throw me somewhere, they shouldn't care about me at all, they benefitted from me [lit: saw good from me] as long as they did, now no one benefits from me]" reflecting that because of their age and changing context, they see themselves as useless to their family - worthy of being thrown somewhere and forgotten when they die. The changing economic conditions are inexorably linked with the shifts in gender roles, making Mire doubly illegible, and sentencing them to death. Burrnesha is not a tradition that meshes well with modern nationalism. It works very well in patrilineal, patrilocal rural areas that usually live on subsistence farming, but it is greatly at odds with Western ideological and economic regimes.

Burrnesha remain satisfied with their lives, despite what many perceive as changing times. In fact, most videos hold that the freedom is coming from the West is to save the burrnesha, and Albanian women in general. In this context, it makes sense as to why many of the interviewers ask burrnesha if they would go back on their oath. This incessant questioning illustrates the strength of colonial gender. For example, when Bedri speaks in the ITV clip, it is clear he is responding to a question about "renouncing" his role. Bedri cuts the reporter off: "O burr! Se jom I knaqun e e kom zgjedh ket jet me koker shpirti, e do ta jetoj deri ne pik te fundit [Oh man! Because I am happy, and I chose this life with the greatest will and greatest pleasure of my soul and I will live it to the end]" (ITV 2018). Interview after interview, though life has not been easy, burrnesha show how much they have enjoyed their lives and 
special roles, and that they would not want it any other way. Unfortunately, their wishes mean little to journalists, the majority of whom persist in seeing the practice negatively.

Burrnesha are caught at the fault line of isolated mountain tradition and neo-liberal/globalized mass media. It is unclear what the outcome of this ambiguous position will be. So far, it seems that burrnesha are losing ground, without an accompanying societal de-centralization of heterosexuality. Most media sources depict the required celibacy of burrnesha as backwards. Yet, Albania makes no significant effort to grant women rights without having to make this allegedly terrible sacrifice (that is a very rare occurrence anyway). The Western onlooker determines that sex - the alleged meaning of life - is too steep a price to pay for freedom, and seems to define freedom as the ability to have sex with whomever one wants. In the context of homonationalism, there is another dynamic: "the pejoration of a traditional gender role and its assimilation to the stigmatized modern "homosexual" identity, a process we see occurring in places as distant as Thailand and East Africa, are occurring in the Balkans as well" (Dickemann 1997, 201). These dynamics seem to usher death for the burrnesha from multiple fronts.

\section{Re-Defining Burrnesha}

A handful of videos reviewed here do not concern burrnesha as they have been traditionally understood. Some of them use the term "burrnesha" as a figure of speech rather than as a reference to a tradition. This shows a shift in the use of the term, to one that is more in line with Western gender and assumes compulsory heterosexuality. One video is about a woman put into jail by the communists for her pan-Albanian sentiments (Albanian Report 2016). She is referred to as a burrnesha here on account of her strength and it is unclear if she also made some oath of celibacy. Another misuse of the term burrnesha is found in a video where a woman politician in Albania encouraged her supporters to give a salute of loyalty. Perhaps she was referred to as burrnesha because she was tough and because coerced a whole crowd into saluting and pledging allegiance to her (Top Channel Albania 2018). Finally, in another video, an imam is saying that "indeed, even in Kosovo there are burrnesha!" (Mesazhi Islam 2014). He discusses some women who did not have brothers but still took charge by donating money to the mosque. It is possible that he is aware of the Western fascination with burrnesha and is referencing that. Usage of the term as in the above cases hints at some cultural knowledge of the practice. Yet, they shift meaning of the word to the purposes of the speaker: connoting a strong woman within the framework of compulsory heterosexuality. This understanding of burrnesha is relevant in the context of nationalism. The nation needs fertile heterosexual women to bear men who can fight more (Yuval-Davis 2003,13). Women are valuable because they can bear sons to pass down the family name (Whitaker 1981). 
It could be possible that these and other nationalist logics are another way that modern Western ideology has influenced social forces that complicate the existence of burrnesha.

In the context of what can be described as gender respectability politics, burrnesha can be seen as an embarrassment, and not necessarily because of their masculine traits. Just as some nationalist discourses might argue that the strength of the nation comes in not having any gay men, the erasure of burrnesha could be attempting to remove gender transgression that does not serve respectability and capitalism. This is especially the case when under the Western gaze, Albanians seem to be trying to seem 'more heterosexual' in order to be more prestigious. The frequent framing of burrnesha as backwards and odd in Albanian media makes this clear. Men's traits will continue to be privileged in the Albanian communities (and Western contexts) but women continue ridiculed if they are not monogamously heterosexual.

I have faced significant pushback from some people with whom I have discussed my identification as a burrnesh, from multiple angles. Some take issue with my identification with the tradition because they consider it to be backward, and something that will open me to ridicule. Others emphasize that transgressing gender norms is embarrassing. Still more assert that my life cannot be complete without heterosexual marriage and I should not limit myself to a life they see as incomplete. All this puts aside that I identify as asexual, and would have had nothing to do with sex or relationships even if this tradition never existed. Furthermore, I identify with masculinity, so I would have been transgressing gender norms anyway. Though they have converged in my case, asexuality and burrnesha need not be related. Burrnesha are a diverse group that are living contradictions to the claim that one needs to be married to be happy, and that gender is rooted in biology. Perhaps the problem lies in the fact that many Albanians would like to think of themselves as civilized and on par with some imagined Western level of gender equality. Yet even in the West, women are oppressed, though in different ways based on their race, class, gender, and sexuality. The lack of sincere progress in improving the lives of Albanian women is hidden under the myth of having 'progressed' to the point that they don't 'need' burrnesha anymore. The existence of the burrnesha complicates many Albanian's opinions of themselves as civilized Europeans.

\section{Conclusion}

This look at the treatment of burrnesha primarily in video media as accessed on YouTube has illustrated a narrative that holds the power to find burrnesha, define and judge them, and conclude that they are fit for death a reason for celebration. The observers hold a level of power over the burrnesha, which legitimizes their claims and cements their superiority. Such attitudes are present across sources. The sources at the margins of Western power had particularly negative discourses, as if to comparatively argue their 
humanity in picking apart the burrnesha. Most of the Albanian sources in particular sought to distance themselves as far as possible from the tradition as evidenced by the way they presented the burrnesha. All this begs the question as to why a group of no more than one hundred gender-variant individuals scattered across rural Albania have garnered so much attention and provoked such reactions from national and international media. One also wonders why the old age of the burrnesha and their (supposedly) dwindling numbers are so emphasized with glee. The answers to these questions must necessarily take into account the historical and continued power relations between the West and the Balkans, especially Albania and Kosovo, as well has the history of Western destruction of indigenous gender practices throughout history.

The fact that burrnesha are in fact not dead yet allows for them to counter many of the clear cut and hegemonic discourses about them. They show that there is more to the tradition than simply a 'solution' to all the men dying, and even more than a choice for more freedom. It is a response to a varying and complicated set of life circumstances and opportunities that make life as a woman untenable for some. It is also a powerful testament to the impossibility that all humans will fit into a strict un-transgressable gender binary. It is unclear what will happen to the tradition in the changing circumstances in Albania, but as long as the burrnesha can speak, they can provide a counter-narrative to a discourse that has so far been authoritative over their existence.

Ahmed, Sara. 2006. Queer Phenomenology: Orientations, Objects, Others. Duke University Press.

Albanian Report. 2016. "Burrnesha a Tropojes Rukie Rama." YouTube, Feb 25, 57:12. https://www.youtube.com/watch?v=wQhvt0h0948

Apostolova, Vesselina. 2013. "Sworn Virgins." YouTube, Nov 12, 2:05. https:// www.youtube.com/watch?v=Yd4Dwe-_XaE

Daring, C. B., Rogue, J., Shannon, Deric., and Volcano, Abbey, eds. 2012. Queering Anarchism: Addressing and Undressing Power and Desire. Edinburgh: AK.

Deutsche Welle (Eng). 2013. "Albania: The Women who Live as Men: European Journal." YouTube, Mar 28, 6:42. https://www.youtube.com/watch?v=XO6LKIn-cMQ

Dickemann, Mildred. 1997. "Balkan Sworn Virgins." Murray, Stephen O. and Will Roscoe. Islamic Homosexualities: Culture, History, and Literature. New York: New York University Press.

Erafilm Albania. Mar 29, 2015. "Sworn Virgin Trailer." YouTube, 1:59. https:// www.youtube.com/watch?v=IQAEWKQ-7oc

Goethe-Institut Brussels. 2016. "Europe's Last Men-Women: 'Sworn Virgins'." YouTube, July 25, 1:53. https://www.youtube.com/watch?v=Gz2kDXCMC38

GQ. 2014. "The Sworn Virgins of Albania." YouTube, Mar 10, 3:40. https://www. youtube.com/watch?v=4G47jIVoXWM

Grémaux, Rene. 1992. Franciscan friars and the sworn virgins of the North Albanian tribes. Religion, State and Society, 20 (3-4): 361-374.

Horvath, Aleksandra Djajic. 2009. "A Tangle of Multiple Transgressions: The Western Gaze and the Tobelija (Balkan sworn-virgin-cross-dressers) in the 19th and 20th Centuries. Anthropology Matters, 5 (2): 1-6. 
Howard, Yetta. (2007). A Review of: "Sara Ahmed. Queer Phenomenology: Orientations, Objects, Others ": Durham: Duke UP, 2006. Women's Studies. Taylor \& Francis Group. https://doi.org/10.1080/00497870701420248

In the Now. 2016. "Albanian Sworn Virgins | Women who Become Men." YouTube, Apr 12, 1:33. https://www.youtube.com/watch?v=F1WsPWw9X34

ITV News. 2018. "The 'sworn virgins' of Albania: Women who have lived their whole lives as men | ITV News." YouTube, May 14, 2:21. https://www.youtube.com/ watch?v=1b32j8zGGrY

Ivica Milicevic Audiobooks. 2017. "Albania Sworn Virgins.” YouTube, Aug 21, 2:28. https://www.youtube.com/watch?v=WH2DmF6JxqY

Jezernik, Božidar. 2004. Wild Europe: The Balkans in the Gaze of Western Travellers. London: Saqi Books.

Journeyman Pictures. 2016. "Wild Flower | Trailer | Available Now." YouTube, Dec 14, 1:46. https://www.youtube.com/watch?v=dLc5WeNCyQk

Klan Kosova. 2017. "Mire Lajqi, virgjëresha e Dukagjinit - 28.09.2017 - Klan Kosova." YouTube, Sep 28, 6:21. https://www.youtube.com/watch?v=22ggicLnvZY

Lugones, Maria. 2007. Heterosexualism and the Colonial/Modern Gender System. Hypatia. Indiana University Press, 22 (1): 186-209.

Mbembé, Achille and Meintjes, Louise. 2003. Necropolitics. Public culture, 15 (1), 11-40.

Mesazhi Islam. 2014. "Kush tha se ne Kosove nuk ka Burrnesha." YouTube, July 10, 2:14. https://www.youtube.com/watch?v=4qalgOVYMxk

NatGeo. 2007. "Sworn Virgins | National Geographic." YouTube, May 24, 3:52. https://www.youtube.com/watch?v=RIIJ990jUfU

Ora News Lajme. 2013. “'Virgjëreshat e betuara shqiptare' në fokusin e 'Daily Maill.' YouTube, Mar 28, 1:13. https://www.youtube.com/watch?v=1sh2G0bx13M

Ora News Lajme. 2018. "Ora News - Burrnesha Diana, virgjëresha e betuar që zgjodhi të jetojë si burrë." YouTube, Mar 8, 1:38. https://www.youtube.com/ watch?v=-CEDEwTTXIc

Papantonopoulou, Saffo. 2014. "Even a Freak Like You Would Be Safe in Tel Aviv': Transgender Subjects, Wounded Attachments, and the Zionist Economy of Gratitude." Women's Studies Quarterly, 42 (1/2): 278-293.

Puar, Jasbir K. 2008. Terrorist assemblages: Homonationalism in Queer Times. Durham, NC: Duke University Press.

Report TV. 2013. "SHBA, Jill Peters, dokumentar për Burrneshat e Shqipërisë Veriore." YouTube, Sep 1, 2:00. https://www.youtube.com/watch?v=nvzTfOm4egM

Report TV. 2014. "A1 Report - Mediat e huaja risjellin fenomenin e burrneshave." YouTube, Mar 12, 1:39. https://www.youtube.com/watch?v=CJBgR7xltjY

Rexhepi, Piro. 2016. "EUrientation anxieties: Islamic sexualities and the construction of Europeanness". EU, Europe Unfinished: Mediating Europe and the Balkans in a time of crisis, Rowman \& Littlefield International, 145-161.

RT. 2009. "Declaring a life of chastity." YouTube, Apr 13, 3:02. https://www.youtube.com/watch?v=h6uZY5rwPMQ

RT. 2016. "The Sworn Virgins of Albania (RT Documentary)." YouTube, Dec 18, 26:34. https://www.youtube.com/watch?v=3UUikqpotiE

RTV KLAN. 2015. "«Burrneshat», pretendent për çmim në Festivalin e Berlinit." YouTube, Feb 12, 1:19. https://www.youtube.com/watch?v=-_rap2PxpWc 
RTV Klan. 2015. "Zona e Lire - Burrnesha. Filmi i Grave Burra ne Berlinale." YouTube, Feb 23, 36:44. https://www.youtube.com/watch?v=40TNtzp3fRo

SBS Australia. 2010. "Women Forced to Live as Men." YouTube, July 15, 13:42. Journeyman Pictures, 2016. https://www.youtube.com/watch?v=J-Pe3f6Swos

Sedgwick, E. K. 1990. Epistemology of the Closet. CA: UC Press, 1-36.

Seeker Stories. 2015. "Why these Virgin Women Live as Men." YouTube, July 20, 4:34. https://www.youtube.com/watch?v=W2xU-uXnbQY

Suleymani, Duffy. 2016. "Burrnesha - Diana Rakipi 2016 HD." YouTube, Mar 4, 3:11. https://www.youtube.com/watch?v=BA3b4wnB67A

Top Channel AL. 2016. "Pasdite ne TCH, Pjesa 4." YouTube, Nov 8, 13:08. https:// www.youtube.com/watch?v=kt_p41B-1Sg

Top Channel AL. 2016. "Rrefehet Illmija: Ja pse zgjodha te jetoj si burre." YouTube, Feb 18, 3:09. https://www.youtube.com/watch?v=eiriwXuAr0w

Top Channel Albania. 2018. "Marshi i LRI-së/ Forumi rinor politik, si repart ushtarak." YouTube, Aug 26, 1:19. https://www.youtube.com/watch?v=rPTmbDMAPMs

Tujani, Sara. 2016. "Burrnesha: When She Became a He." YouTube, June 7, 19:29. https://www.youtube.com/watch?v=br4FZIX9Jd0

TV 2000. 2018. "Burrnesha - Humor Shqip.” YouTube, Apr 27, 5:11. https:// www.youtube.com/watch?v=Jzt5G8t_TF0

Vizion Plus. 2014. “Oktapod: Rrefehet Burrnesha Diana." YouTube, Nov 14, 35:25. https://www.youtube.com/watch?v=k6JPL3AVo8s

Whitaker, Ivan. 1981. "A Sack for Carrying Things': The Traditional Role of Women in Northern Albanian Society." Anthropological Quarterly, 54 (3): 146-156.

Young, Antonia. 2010. “'Sworn Virgins': Cases of Socially Accepted Gender Change." Anthropology of East Europe Review: 59-75.

Yuval-Davis, Nira. 2003. Nationalist Projects and Gender Relations. Nar. Umjet 40 (1): 9-36. 